\title{
What Counts as Literacy in Early Childhood?
}

\section{Citation}

Snow, C. E. 2006. What Counts as Literacy in Early Childhood?, in Blackwell Handbook of Early Childhood Development (eds K. McCartney and D. Phillips), Blackwell Publishing Ltd, Oxford, UK. doi: 10.1002/9780470757703.ch14

\section{Published Version}

doi:10.1002/9780470757703.ch14

\section{Permanent link}

http://nrs.harvard.edu/urn-3:HUL.InstRepos:34785388

\section{Terms of Use}

This article was downloaded from Harvard University's DASH repository, and is made available under the terms and conditions applicable to Other Posted Material, as set forth at http:// nrs.harvard.edu/urn-3:HUL.InstRepos:dash.current.terms-of-use\#LAA

\section{Share Your Story}

The Harvard community has made this article openly available.

Please share how this access benefits you. Submit a story.

Accessibility 


\title{
What counts as literacy in early childhood?
}

\author{
Catherine E. Snow \\ Harvard Graduate School of Education
}

September 2004

To appear in K. McCartney \& D. Phillips (Eds.), Handbook of early child development. Oxford: Blackwell. 
Issues of literacy development are a major source of worry to American educators. Worries about whether U.S. children read well enough emerge every time results of an international comparison are published. Many of the provisions of the No Child Left Behind legislation are directed toward more stringent assessment and more effective instruction in literacy. Concerns about school readiness have led to interest in the quality of preschool programs, to the expansion of preschool programs designed as prevention or intervention efforts for children of low-income parents, and to movements toward publicly financed kindergarten classrooms for four-year-olds, to provide more time for children to acquire the skills they need for school.

Is all this attention really justified? What kinds of literacy skills do young children possess, and what is the evidence that those levels are unsatisfactory? The focus of this chapter is literacy, in particular a consideration of the many and varied child capacities that have been identified as related to literacy outcomes among children under the age of eight. The argument I will make is that conceptions of literacy, and definitions of what counts as literacy, vary enormously, and that those varying conceptions are reflected a) in divergent claims about how well children are doing, b) in differing conclusions about whether some early childhood accomplishments really matter to later literacy development, c) in differing foci for the design of early childhood education and intervention programs, and d) in varying emphases on skills selected for inclusion in the assessment of literacy in the early childhood period.

I start with a brief description of children's literacy development-what the mythical 'average child' can do at ages up through grade three. Then I turn to a description of the disagreements among literacy researchers, the issues that divide them and that lead them to differing conceptions of literacy itself. I elaborate those differences by describing how they shape their advocates' answers to key questions about the central topics of interest: preschool literacy accomplishments, precursors to later literacy development, design of prevention/intervention programs, and assessment.

\section{The literate child}

Everyone agrees that literacy is a complex and multifaceted skill which changes enormously as it is acquired. The Committee on the Prevention of Reading Difficulties in Young Children (National Research Council, 1998) outlined the literacy skills to be expected of children at different points up through grade 3. Table 1 presents a truncated version of the developmental guidelines they presented ${ }^{1}$. The typical three-year-old can

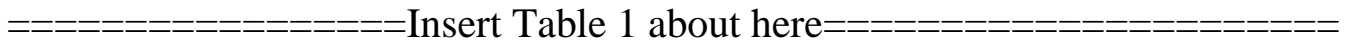

recognize some books by their covers, knows how to hold books upright and turn pages, listens when read to, expects to be able to understand pictures in books, may distinguish pictures from print, may recognize some letters, and produces purposeful-looking scribbles. The typical four year old has learned to recite the alphabet and to recognize several letters, connects events in stories to 'real life,' understands that stories are different from notes or lists, may produce rhymes or alliterations, and may scribble, pretend-write, or draw with a communicative purpose. The typical kindergartner knows about titles and authors of books, may track the print when being read to from familiar

\footnotetext{
${ }^{1}$ Even the selection of capacities to focus on in a table like this constitutes a theoretical commitment to a certain view of literacy. I attempt in this section, thus, to select for discussion a fairly wide array of relatively uncontroversial skills.
} 
simple books, can name all and write most of the letters, can recognize and spell some simple words, spontaneously questions events in stories and information books, and uses mostly invented spelling in writing. The typical first grader is starting to get a serious handle on the system of writing, is able to read accurately and fluently texts that include previously taught spelling patterns, uses letter-sound correspondence to sound out new words, spells with a combination of conventional and invented spelling, monitors her own writing and reading for correctness, and understands the differences among a wide variety of texts (informal notes, informative texts, stories, poems, slogans, lists, and so forth). In $2^{\text {nd }}$ and $3^{\text {rd }}$ grade, the typically developing child becomes increasingly accurate and fluent with an ever wider variety of spelling patterns, becomes able to tackle more complex texts independently, knows how to seek help from a dictionary or an adult with difficult words or ideas, writes a wide array of text-types increasingly conventionally and with ever greater capacity to revise independently, and infers the meanings of unfamiliar words encountered in otherwise comprehensible text. Of course, literacy growth continues after grade 3 - the capacity to read with different purposes, to learn from reading, to critique the text, to compare and contrast points of view when reading, and in other ways to produce and process complex tests may continue to develop through adulthood. But the skills acquired by $3^{\text {rd }}$ grade (acquired only, of course, if children enjoy home, preschool, and primary grade environments that support these learnings) constitute the firm foundation on which those more complex skills depend.

\section{So how do we define literacy?}

The conceptions of literacy and literacy development that guide the work of prominent researchers and educators vary along a number of dimensions, in ways that are often implicit in the thinking and writing of their proponents. To help explicate the nature of the major controversies in the field of literacy development, I list some of those dimensions, with the caution that these various continua are certainly not independent of one another, and that a different parsing of the variation might be equally defensible:

Componential vs. holistic. Literacy can be viewed as the product of an array of component skills, all of which are necessary to high-level performance. For example phonological awareness, letter knowledge, automaticity in reading letter sequences, and lexical access could be identified key component reading skills. Holistic thinkers see meaning-making as the central defining feature of good reading, are inclined to think of reading as a single, integrated capacity, and often deplore attention to isolated components in reading instruction or assessment.

Solitary vs. social. Literacy can be viewed as an individual cognitive accomplishment, as an activity that is exemplified by 'curling up with a book.' Alternately, it can be viewed as an essentially interactive, collaborative activity embedded in social purposes, even when the act of reading itself is solitary. The solitary view sees reading and writing as primarily an inside-the-head psycholinguistic process, a process that involves the development of new neural pathways and organizations and that is subject to risk of failure due to factors of anatomy or neural processing. The social view brings in a political dimension - reading skill provides access to power and to knowledge, and failure can result from the unwillingness of those who hold power to share access. 
Instructed vs. natural. Literacy can be seen as dependent on instruction, with the corollary that quality of instruction is key. This view emphasizes the developmental nature of literacy-- the passage of children through successive stages of literacy, in each of which the reading and writing tasks change qualitatively and the role of the instructor has to change accordingly (see Chall, 1996). Alternately, it can be seen as a natural product of growing up in a literate society, easy to acquire without explicit instruction if motivation and opportunities for practice are available. Those who hold the natural view minimize attention to developmental change by attributing equal value to various forms of participation in literacy.

Functional/technical vs. transformational/cultural. Literacy can be viewed as a technical, functional accomplishment that simplifies tasks like participation in the workforce, accessing information, or navigating in a strange neighborhood. Functional views tend to focus on print-linked aspects of literacy, like filling in forms and deciphering signs. Alternately, literacy can be viewed as a factor in one's personal and social identity, a source of empowerment and reconstruction of the self, and a force in transforming the practices, rules, and relationships that constitute culture. This view emphasizes the consequences of literacy for ways of talking and thinking.

Singular/coherent vs. multiple/varied. For some, the definition of reading is rather simple-it is what one does with a book or newspaper, it is what gets assessed on a high-stakes test. Others emphasize the contrast among, for example, the process of reading a religious text that has been largely memorized and is meant to be believed literally, of reading a poem with an interpretive stance, of reading a contract with a critical stance, and of reading a bus timetable seeking specific information. In this multiple-literacies view, the variation across literacy tasks is more striking than the similarities among them.

School-focused vs. home- and community-focused. For some, literacy tasks engaged in at school constitute the prototype for literacy, whereas others argue that most literacy activities and much literacy learning occur outside school, in the home, in the context of religious observance, daily life tasks, and community involvement.

Two straw persons. To understand how these various dimensions define contrasting conceptions of literacy, let us start simply by describing two views of literacy that might be located at the extremes of all these various continua. A group of scholars, including David Barton, James Gee, and Brian Street, have coined the term The New Literacies (see, for example, Barton \& Hamilton, 1998; Gee, 1996; Street, 1987, 1995, 2001; the papers in Barton, Hamilton \& Ivanic, 2000) in an attempt to emphasize their commitment to a notion of literacy that is social, community-based, culturally-defined, varied, and potentially transformational. This view of literacy explicitly rejects a focus on individual skills, downplays the necessity of schooling or formal instruction, and tends to ignore information about development, e.g., differences in how novice and expert readers interact with print. It accepts participation in a multi-party literacy event as evidence of being literate, without worrying about disparities in the skill levels or contributions of different individuals. Prototypical literacy events for those who hold this view might include 'tagging' (spray painting signatures on public surfaces), producing political banners, collaborating with friends to figure out a bus timetable, or contributing to an on-line discussion group. 
In contrast, literacy as embodied in many of the policies associated with No Child Left Behind is viewed as an instructed skill, accomplished by the child operating individually, as a technical achievement exercised primarily and most crucially in school settings, analyzable into component skills, and unconnected to political or cultural commitments (e.g., Reyna, 2004). This is the view of literacy that might lead someone to say, 'If you test a child on basic...reading skills, and you're "teaching to the test," you're teaching... reading' (Bush, 2001). It is a view of reading that promotes giving teachers explicit guidance about instruction focused on specific components within the reading process (Moats, 2004), and that operationalizes reading comprehension with tests of forced-choice answers to questions about brief passages. Prototypical literacy events within this view include reading a novel, studying for a test, or making a note to oneself.

Of course, in these descriptions both these positions are presented in a way that is somewhat stereotyped and exaggerated. Probably any reading researcher would insist on modifications and modulations of one of these positions before endorsing it. But it is these more unmodulated versions that often dominate policy and practice decisions, and that form the basis for the sometimes rabid political battles over reading instruction and curriculum design $^{2}$. In the discussion that follows we will refer to the first of these views as the Holistic and the second as the Componential, though any of the other dimensions that differentiate them could also have been selected as the basis for naming each complex of beliefs.

Accepting these stereotyped descriptions, then, simply as markers for the range of variability in definitions of literacy, we turn to the major goals of this chapter. What are the implications of these varying views of literacy for thinking about young children's literacy accomplishments, and in particular about the nature of individual and group differences in these accomplishments? For deciding which early accomplishments are crucial to later success? For identifying the factors related to the development of literacy in young children, and thus making recommendations about the experiences young children should have, at home and in preschool and elementary classroom settings? And for making decisions about assessing literacy and establishing literacy goals for the society?

\section{The key early literacy and precursor skills}

Young children, before they have had any formal literacy instruction, display many capacities and skills which can be viewed as directly relevant to their literacy development. Beliefs about exactly which of those capacities are crucial preliteracy skills, and which should be promoted by parents and preschool teachers, are, of course, determined by one's view of the nature of literacy itself.

There is general consensus that early emerging literacy-relevant skills include the capacity to recite the alphabet, to name and print letters, to spell simple words including one's own name, to recognize letters and signs in the environment, to identify books by their titles, and to handle books and other literacy artifacts appropriately (see Table 1). These sorts of capacities are seen by more Holistic thinkers as evidence that children are participating in authentic literacy activities, enacting the literacy practices they see their

\footnotetext{
${ }^{2}$ Perhaps the best way to learn about these straw-person positions is to read each side's characterization of
} the other. See, for example, the exhanges at http://cars.uth.tmc.edu/debate/ 
parents engaging in, or displaying cultural routines their parents value (e.g., Teale \& Sulzby, 1986). They would, for example, view a child scribbling on a piece of paper, seated next to his mother while she makes a shopping list, as a full participant in a familial literacy practice, and would describe children 'pretend reading' a familiar story book as displaying sophisticated literacy skills.

These same capacities are seen by Componential thinkers as of varying importance. Certainly naming letters correctly and writing by using memorized or invented spellings are seen as important accomplishments; these reflect two skills that relate directly to later literacy outcomes: letter recognition and phonological analysis (Bond and Dykstra, 1967; see Bowey, in press, for an extensive review). Reciting the alphabet and reading environmental print are not valued so highly by Componential thinkers, as these accomplishments do not predict later literacy outcomes very robustly. The scribblings of the child helping his mom with a shopping list would be analyzed as representing a very early stage of literacy development-one in which the child understands that the graphic symbols which represent speech have unique features, but has not yet incorporated specific knowledge about letter shapes into his writing. Pretend reading might be seen as evidence that the child has had extensive book-reading experience (Sulzby, 1985), itself a predictor of good literacy outcomes, but not as offering much evidence about the child's actual literacy skills, since the child is probably using the pictures rather than the print as a guide in the performance.

Componential thinkers identify as crucial one set of skills that holistic thinkers are inclined to downplay-phonological analysis skills, leading to phonemic awareness (Byrne \& Fielding-Barnsley, 1989). Phonemic awareness is the understanding that words are made up of smaller sounds, or phonemes. This is a key insight for children who will be learning to read in an alphabetic orthography, since the graphic symbols in such a system mostly represent phonemes. Thus, children with no awareness of phonemes will be puzzled by explanations of how to use print to represent speech. Phonological awareness is seen as one of the key early emerging literacy-relevant skills, but it is of course a capacity which is rather remote from the construction of meaning that holistic thinkers focus on as the central literacy activity.

Holistic thinkers might, on the other hand, emphasize the importance of a number of accomplishments of 'well-read to' preschoolers that may seem on their surface to have little direct relation to literacy. Such accomplishments include, for example, the use of literary or formal language styles when engaging in pretend reading, or when dictating a text to an adult (Purcell-Gates, 1988, 1991). Other oral language skills likely to be possessed by children who will learn to read easily include academic language skills such as giving formal definitions or telling coherent narratives (Snow, Tabors \& Dickinson, 2001; Tabors, Roach \& Snow, 2001). Such capacities reflect the children's history of participation in a wide array of cultural practices related to literacy, including certain language forms and conventions. Listening to books read aloud, reciting religious texts, or pointing to the word salad while ordering a burger from the menu at McDonald's would all be treated as important evidence of emergent literacy by holistic thinkers.

\section{Factors related to literacy outcomes}

As hinted above, early emerging capacities that seem conceptually to relate to literacy may not all be equally good as predictors of later literacy outcomes. Meta- 
analyses of longitudinal studies of literacy development (Scarborough, 1998) make clear that some early emerging skills are highly reliable predictors of later outcomes, whereas others, skills that seem on the face of it to be equally relevant to literacy, simply do not show such robust correlations.

The fact that some skills correlate with later literacy outcomes does not, of course, implicate those skills as the determinants of later literacy outcomes. Take letter knowledge as an example. The ability of 4-year-olds to name letters correlates with their tested $2^{\text {nd }}$ grade reading scores at a level of about .60. But is that because naming letters is crucial to reading? Clearly not. In Russia, a country with high literacy achievement, young children are not expected to learn to recite the alphabet. In northern Europe (where children in general learn to read quite successfully) teaching young children letter names is avoided, on the theory that the letter names will interfere with the phonemevalue the letter signals. Letter names are typically syllables - the letter B is named bee, the letter F is named eff and so on. Such correspondences can help children see soundletter correspondences when the letter name is by chance homophonic with a segment of the word (i.e., children have an easier time identifying the initial sound of beet than of boat, and recognizing the final sound of deaf than of half , Treiman, Tincoff \& Richmond-Welty, 1996). But if children used the letter-name strategy exclusively, trying to read by relying on letter names rather than letter sounds, this would cause great problems, vide the recollections of Garcia Marquez (2003) about his early theories of orthography:

Me costó mucho aprender a leer. No me parecía lógico que la letra $m$ se llamara eme, y sin embargo con la vocal siguiente no se dijera emea sino ma. Me era imposible leer así. (p. 112)

(I had a hard time learning to read. It didn't seem logical to me that, given that the letter $m$ was called eme, when it was followed by a vowel you were supposed to say ma and not emea. I couldn't read like that.) CES translation

Knowing letter names may also contribute directly to reading skill by helping children differentiate and remember letters. Alternately, knowing letter names may simply reflect having had lots of experience with print and with book reading, on the basis of which children have learned many things that help them with reading. So perhaps the letter names simply serve as a proxy for other kinds of learning that are themselves causally related to better reading skills.

One of the most robust long-term predictors of good literacy outcomes that can be measured in early childhood is vocabulary. Children with large oral language vocabularies are very unlikely to have problems learning to read-a finding that renders the huge social class differences in vocabulary size among preschool-aged children (Hart \& Risley, 1995) particularly important. The relationship of vocabulary to success in reading comprehension is easy to understand — clearly, it is hard to comprehend texts containing many words one does not know. In some studies vocabulary correlates more strongly with global comprehension than with word-reading measures even in $2^{\text {nd }}$ grade (Muter, Hulme, Snowling \& Stevenson, 2004), but in other studies (e.g., Snow, Nicholson, Kurland \& Tabors, 1995), the relationship between vocabulary and word recognition is also quite strong. Again, it is difficult to discern whether $1^{\text {st }}$ graders with large vocabularies have better literacy skills simply because they come from homes and 
preschools that have provided richer environments for both language and literacy development, or whether knowing more words has a direct impact on the ease of learning to read. Walley (1993) and Goswami (2001) would argue for the latter claim, suggesting for example that phonological awareness is directly enhanced by knowledge of more words, since that provides the opportunity for more precise comparison of the sounds that differentiate phonemically similar words, e.g., hen, pen, ten but also head, peck, tell and held, pecked, tent.

Phonological awareness has been demonstrated to relate to literacy outcomes about as strongly as vocabulary in Kindergarten and grade 1 (National Research Council, 1998). Again, the reasons for this seem obvious. The task facing early readers is figuring out, first, that letters represent sounds, and second, which particular letters represent which particular sounds. That task presupposes that learners have some sense of what sounds are-yet the sounds that can be systematically related to letters are abstract, often unpronounceable, and difficult to think about. This fact differentiates alphabetic orthographies from syllabaries, in which the graphic symbols represent units like $f a, m o$, or $b u$ that are relatively stable and psycholinguistically accessible. The capacity to think about phonemes, to recognize that at some level the /b/ sound in the three words bat, tub, and trouble is the same abstract entity (despite the many differences in the actual articulatory and acoustic features of /b/ in those three positions) is prerequisite to acquiring an understanding of alphabetic systems - in other words, that those three different sounds should all be represented by the letter B. Thus, whether children are being expected to learn letter-sound correspondence from explicit phonics instruction ("This letter is a B, it makes a /b/ sound, we hear it at the beginning of words like bat, bell, big, bop, and bug."), or from more meaning-focused instruction ("Let's all read together. This book is about Bob the Big Bad Bug."), having an understanding about phonemes as isolable units is likely to help. The helpfulness of phonemic awareness to children exposed to initial literacy instruction has led to calls for universal instruction in phonological awareness and considerable attention to phonological awareness within early reading curricula (National Institute of Child Health and Human Development, 2000). Unfortunately, such curricula have led in some cases to the notion that phonological awareness is an end in itself, rather than a steppingstone to better literacy learning. There is no evidence that learners need or benefit from phonological awareness curricula after grade 2; there is evidence that a total of about 20 hours of explicit attention to phonological awareness is sufficient to produce the desired effect in almost all children (Ehri et al., 2001); and there is evidence that supporting children to write with invented or estimated spelling generates phonological awareness as effectively as explicit curricula (e.g., Watt, 2001).

A striking and frustrating fact about literacy development is that it is much less likely to proceed in a trouble-free manner for certain large groups of children. Some sources of risk for literacy failure are unsurprising — mental retardation, hearing problems, language disorders, and dyslexia, for example. These individual risk factors should be responded to with extra attention to quality and intensity of literacy instruction. Other sources of risk include social factors such as poverty, being a nonnative speaker of the school language, and being a member of an ethnic or racial minority group (National Research Council, 1998). Holistic and Componential thinkers differ radically in their explanations for the heightened risk of these groups. Holistic thinkers attribute their 
greater probability of reading failure to political factors, arguing that it reflects the inequitable distribution of resources (nutrition, health care, safe and adequate housing, books, well-prepared teachers, adequately equipped school buildings), or alternately that it reflects the reduced value of literacy skills to members of groups that will not be given access to power even if they achieve well in school. Thus, they argue, improving reading outcomes for all requires a rethinking of power relations in society as a whole.

Approaches to reading intervention that focus on providing more or more structured instruction are dismissed by Holistic thinkers as irrelevant or even aligned with an agenda of preventing radical social change (Gee, 1999, 2000).

Componential thinkers are more likely to point out that children growing up in segments of the society more at risk of reading failure have less well-developed skills in key areas, such as understanding the functions of print, recognizing letters, manipulating phonemes, familiarity with the language of books, and rich vocabulary. It is these skill differences, they argue, that generate the risk of failure. Thus, rather than societal actions to redress social inequities (which might well, they would admit, be the source of the skill differences), they argue for direct intervention in the domains of deficit: teach letter names, phonological awareness, and vocabulary, and provide experiences with print.

\section{Promoting literacy development at home and in the classroom}

There have been many efforts to mount and evaluate prevention and early intervention programs designed to reduce the risks of poor literacy outcomes associated with poverty and minority status. These programs vary in the age range of the children they target, in the mode of delivery of services, and in sources of funding. Most importantly, though, they differ in the theories that inform them. It is thus, perhaps, instructive to describe examples of a few of these prevention/intervention efforts, from the perspective of their guiding presuppositions about literacy development. In this section I provide brief overviews of four widely disseminated early intervention programs: Early Head Start (EHS), Home Instruction for Parents of Preschool Youngsters (HIPPY), Head Start, and Project EASE. EHS and Head Start are both federally funded U.S. programs, administered under local control but with increasingly stringent performance standards defining their services, and targeted at both children and their families. HIPPY and Project EASE are both programs designed basically to improve mothers' capacities to serve as teachers for their children; HIPPY was originally targeted at younger preschoolers, though it has now been extended to older preschoolers and kindergartners, and EASE was designed originally for kindergartners, but a preschool version is currently being developed as well.

These four interventions are of interest because of what they reveal about the covert or implicit theories of literacy development on which they are based. The original design of HIPPY and the central focus of Project EASE arise out of a componential view of early literacy development, but a componential view in which language skills are identified as the domain in which children at risk for literacy failure most need support and enrichment; print-related skills are included, but given less time than language. Early Head Start is highly convergent with the Holistic view, that improving familial resources across the board, including parental finances, employment, and health status, should generate improvement in child outcomes. That parent-empowerment model was a strong feature of Head Start programs during their first 20-30 years, but more recently the 
emphasis on particular child-outcomes, on enhanced attention to literacy preparation, and on the role of qualified teachers in Head Start classrooms has shifted the Head Start program toward embodying a Componential view of literacy.

Early Head Start. In 1995 as part of the Head Start appropriations bill, the U.S. Congress directed that $5 \%$ of Head Start funds be used for a new program targeted at families of infants and toddlers up to the age of 3 , and that a randomized trial be launched on a subset of the first programs funded under the EHS vehicle. That study recruited 17 sites and 3001 families randomly assigned within site to treatment or control conditions. Data on the children in those families have been collected at child age 14, 24, and 36 months, and again prior to kindergarten entry. In addition, data were collected at those and/or other time points from family members, other care providers, and programs themselves. Since EHS was, like Head Start, charged to improve children's school performance, the child measures included assessments of language and cognition, and school readiness measures at the prekindergarten assessment.

Services provided varied across the programs that participated in the evaluation. Most programs used a case management system, to provide a wide array of services to families, including guidance about finding child care, adult education services, medical care, transportation, and employment. However, regular attention to teaching parents about ways to improve children's pre-academic skills was prescribed as part of each home visit, and many programs also provided access to child group care settings designed to ensure growth in domains relevant to school readiness.

The measured child outcomes reflected these emphases on early school-related skills; child scores on measures of cognition and language were higher in the program than the control group (Love et al., 2002). Furthermore, participation in the program was associated with improved parenting practices across a variety of domains, including more stimulation of children's language and learning, and less severe punishment strategies. In addition, program families showed higher levels of participation in education or job training during the program (Love et al., 2002).

Head Start. If popularity and continued congressional support were the metric, Head Start would have to be considered the most successful federal program ever launched. During its first 40 years, nonetheless, Head Start underwent a couple of periods of dramatic change. The first such period was close to its beginning. Head Start was founded with rather unrealistic expectations concerning the size of the effect that could be expected from relatively short term, focused, and low-cost programs. It grew quickly in its early few years from being a summer program focused on child learning to being a year-round program that targeted health, nutrition, parent and community involvement as well as education. Some argued, in fact, that in that period education was neglected in favor of all the other components, and that Head Start classrooms paid insufficient attention to providing the basis for literacy learning in kindergarten. For example, the emphasis on parental and community involvement was implemented by hiring many Head Start parents to work in the programs - with the result that the educational services being provided were not professional or even in many cases very enriched beyond what children would have gotten at home (see Richmond \& Ayoub, 1993, and Sigel, 2004, for historical views of Head Start). 
The guidance provided to Head Start under the Bush administration, though, and the provisions of Early Reading First legislation shifted those priorities rather abruptly. Starting in 2003, Head Start programs were required to meet higher standards for the proportion of classrooms with qualified (professionally educated) teachers, and to report on their adherence to a variety of performance standards, which included standards for child knowledge of letters and other specific skills related to school readiness. The impact on instructional activities within the country's Head Start classrooms is not known, but it is very likely that teachers started spending considerably more time on measurable skills such as reciting the alphabet, counting, and recognizing letters and numbers. So far, this shift of attention has unfortunately not generated impressive increments in the skills of Head Start children (Whitehurst \& Storch, 2004).

Interestingly, the enhanced skill focus has alarmed adherents of both views of the nature of literacy. Defenders of Holistic views about literacy deplore efforts to teach 4 year olds literacy skills explicitly, and many Componential analysts would point out that emphasizing letter names and phonological awareness at the expense of attention to providing a rich language environment that would support vocabulary growth might be counterproductive (Snow \& Páez, 2004).

HIPPY. The HIPPY model was devised first in Israel, as a way of intervening with immigrant groups with limited literacy and educational achievement (Lombard, 1994). It involves direct instruction to mothers about ways of using various toys and literacy materials-providing a rather structured set of activities and a relatively scripted way of interacting. A feature of HIPPY is that the maternal instruction is delivered by mothers from the same social class as the participants; this presumably promotes effective communication, ensures that the activities are not seen as being imposed by a distant group, and also provides newly enrolled mothers with evidence that people just like them learned and enjoyed such activities.

HIPPY has been internationally disseminated as a model for early intervention (Westheimer, 2003). It has been used, for example, in the U.S. with low-income families, in The Netherlands with immigrant families, and in Turkey with rural and loweducation mothers. Evaluations in those various settings have shown varied results quite positive short- and longer-term impacts on children in Israel (Lombard, 1994) and in Turkey (Kacigitabasi, 1999), but no lasting documented effects on child outcomes in The Netherlands (Eldering \& Vedder, 1999) and rather mixed and limited effects at various sites where it has been implemented in the U.S. (see http://www.hippyusa.org/Research/research_summary.html). The positive effects that have been documented include general performance in school, rather than literacy skills per se.

Project EASE. Project EASE was devised by Gail Jordan as a prevention program to improve the literacy outcomes of kindergartners attending Title 1 schools in the White Bear Lake School District in Minnesota. It embodied the principle that the major domain in which parents could help their children was language, and that even low income parents could be shown ways to engage in longer, lexically richer, and more extended conversations. Jordan devised curricular materials to support the desired types of interactions, invited parents to training sessions, and had kindergarten teachers assign activities for the parents to engage in with their children. A quasi-experimental study of the first implementation of Project EASE showed significant effects on children's 
language skills, including vocabulary, comprehension, and story telling (Jordan, Porche \& Snow, 2000).

Project EASE has subsequently been implemented in low-income schools in Ohio, under the auspices of the Collaborative Language and Literacy Intervention Project. Comparison of participating children with those in similar schools that had not implemented EASE showed impacts on language skills similar to those found by Jordan, Porche and Snow (2000; Porche \& Pallante, 2004). An adaptation of the EASE program in Spanish has been implemented in Costa Rican kindergarten classrooms, and received with great enthusiasm by parents and children, though results concerning improved child outcomes are not yet available (Rolla San Francisco, Arias, \& Villars, 2004).

Summary of insights from four interventions. All four of these interventions are strongly based in theory — but in somewhat different theories about what is the crucial prerequisite to literacy development, and where intervention needs to be targeted. HIPPY, Early Head Start and Project EASE have also been evaluated using reasonably rigorous quasi-experimental or experimental procedures. The results suggest that HIPPY can work in some settings, and that both EHS and EASE work fairly robustly to improve those aspects of children's skills that they target, though their effect sizes are at best moderate. These programs all are based on a presupposition that effective intervention to reduce risk of literacy failure requires a broad definition of the precursors to literacy success, and requires changing patterns of linguistic and affective interaction as a context for language and literacy facilitation.

\section{Assessing individuals' literacy skills and evaluating literacy in society}

Perhaps the most significant source of evidence about one's commitment to a particular view of literacy is that reflected in a decision about how to assess literacy. High-level literacy is a multi-faceted skill, and devising a way to sample behavior that reflects that skill is not straightforward. Furthermore, the complexities of designing assessments lead many of us to draw conclusions from instruments we know reflect the target domain inadequately.

Ultimately, the issue is that literate individuals are different from individuals with low levels of literacy, or with low involvement in literacy activities, in a wide array of different ways. Some of these are suggested by the findings of a research program showing widespread effects of exposure to print on many domains of knowledge (e.g., Stanovich, West \& Harrison, 1995). One ingenious study in this line of work (West, Stanovich \& Mitchell, 1993) compared two groups of adults selected to differ on literacy propensities. The members of the two groups were identified in airport waiting lounges, and were differentiated on the basis of whether they passed their time reading books or not (this study was carried out before the ubiquity of cell telephones eliminated the possibility of reading with comprehension in any public place). The quality of the book was not taken into consideration, so readers of Danielle Steele were as likely to be chosen as readers of Faulkner. Nonetheless, the 'reader group' scored significantly higher than the 'nonreader group' on measures of vocabulary, world knowledge, author recognition, magazine recognition, and newspaper recognition. Of course, no one would seriously suggest that recognizing that Field and Stream is a real magazine while Fitmess Today is 
not should be an acceptable test of literacy. But it does differentiate more from less literate adults. ${ }^{3}$

So what are the recommendations for assessing literacy in young children? The FACES study, an effort to collect descriptive, longitudinal, multi-cohort data on the Head Start population, uses an instrument called FACES (Family and Child Experience Survey; http://www.acf.dhhs.gov/programs/core/pubs_reports/faces/meas_99_appendix_a.html). This survey assesses such child capacities as knowledge of letters, print concepts, vocabulary, and simple numerical skills, but it also collects considerable observational and interview data about the children included in the sample. The plans to use a test based on the FACES measure to draw conclusions about the progress of children in Head Start classrooms has been sharply criticized by Meisels, Barnett and Kagan (http://www.fairtest.org/nattest/Head_Start_Letter.html) for its neglect of child diversity, because it risks narrowing the Head Start curriculum, and because of the time that would be invested in administering the instrument to every Head Start student.

But if one wanted a test to help identify preschoolers who would benefit from intervention or from access to above-average early literacy instruction, what should one use? Clearly, given the expectations of kindergarten teachers, children who do not know letters and who are completely unfamiliar with the notion that words could be classified by rhymes or by beginning sounds may run into trouble. Even more clearly, children who fall far below age expectations for vocabulary and for knowledge about topics of importance in kindergarten curricula (e.g., number, color, shape, botany, family, community, human biology) are less likely to thrive or to benefit from standard kindergarten teaching. These are domains that might well be assessed in a risk-screening assessment.

\section{Coming to a view of literacy that can inform early childhood practitioners}

So is there a correct conception of literacy? Clearly, neither of the extreme views presented earlier in this paper is defensible in its entirety, and yet both those views make some useful claims. In particular, there are insights from both views that offer guidance for the design of optimally supportive environments for young children's literacy development. Let us return to the dimensions on which they differ to review what both positions might contribute to improved literacy practice with young children.

Componential vs. holistic. There is considerable research evidence that several different domains of skill relate to literacy outcomes. In other words, children can encounter difficulty in learning to read because of deficits in letter recognition, phonemic awareness, automaticity of word reading, or vocabulary - evidence consistent with the componential view. But it is also clear that the essence of operating literately is the central process of constructing meaning, not simply the operation of the various components. It is also true that instruction should not focus on the components without linking them to the central purpose, comprehension. And the worry that children most at risk of literacy failure are also most likely to be provided print-component-focused instruction that fails to emphasize meaning has considerable basis in reality.

\footnotetext{
${ }^{3}$ Readers interested in the nature of the debates between the more holistic and the more componential true believers should read Taylor's (1994) commentary on the Stanovich study; those interested in the study of tongue-in-cheek rhetoric should read Stanovich and West's (1994) response.
} 
In thinking about the design of programs for young children, selecting components to focus on is key. Focusing a lot of time and attention on the limited-scope components (letter recognition, phonemic awareness) can undermine appropriate attention to the large-scope components (vocabulary, extended discourse, world knowledge) that ultimately will explain a good deal more of the variance in reading outcomes. Thus, in effect, both componential and holistic thinkers would strongly support the use of activities in early childhood classrooms that promote active involvement with meaningful literacy, such as reading books aloud and then talking about them, embedding reading and writing activities in language-rich play, and encouraging children to use mixtures of drawing and unconventional writing to express themselves.

Solitary vs. social. Though literacy is ultimately, for the successful reader, an autonomous accomplishment with consequences for psycholinguistic processing and brain development, it remains a social activity for many, and social supports are crucial to its optimal development. Consider the ubiquity of book discussion groups, the role of peer sociability in the popularity of Harry Potter volumes, the motivation to read associated with the expectation of discussing the topic with someone. Children from well-educated families with plenty of money can encounter difficulties learning to read, and when that happens it usually reflects a specific learning problem-a neurological or psycholinguistic cause. Children from poorly educated families with little money have a high probability of encountering difficulties learning to read, and the reasons for that can clearly be traced to political forces--an unwillingness to invest as much money and expertise in their learning as they need. However, it is possible to promote literacy achievement among the children of the politically powerless, and the best way to do so is to provide excellent, well-structured, and literacy-rich preschool programs, and good, structured, explicit instruction in the primary grades. Young children from homes where literacy experiences have been scarce might benefit especially from participation in preschool classrooms where interactions with books are valued social activities, not simply an opportunity for instruction.

Instructed vs. natural. A small percentage of children simply learn to read, without explicit instruction, well before school age (e.g., Davidson \& Snow, 1995). For such children, growing up in highly literate families, reading is indeed a natural product of development. Most children, though, need some help to figure out how reading works, and it is estimated (National Research Council, 1998) that a higher proportion of children fail to learn to read because they have not had adequate instruction than learn on their own, without instruction. For most children, literacy skills get reorganized many times over the course of development, and their literacy knowledge changes qualitatively, as they move from scribbling and pretend reading, to single-letter invented spellings and recognition of only a few familiar words, to more elaborated invented spellings and effortful decoding of regular words, to fluent writing and reading. Understanding those qualitative shifts in literacy skill is extremely important if preschool and primary teachers are to offer optimal, differentiated instruction and support.

Functional/technical vs. transformational/cultural. Literacy skills are a primary predictor of employability, and are strongly related to income (Murnane \& Levy, 2004), evidence of their functionality. At the same time, learning to read can transform lives, in particular the lives of those who have suffered from the effects of illiteracy in a highly 
literate society (e.g., Jacobson, 2004). This is an issue on which both views of literacy are equally correct. Clearly, literacy involves both the accomplishment of technical, print-related skills and the capacity to learn, to write, and to talk in new ways. An excessive focus on the technical aspects of literacy can impoverish access to language and world-knowledge in the educational environments of young children; that is a particular risk for children whose homes provide limited language and literacy stimulation.

Singular/coherent vs. multiple/varied. While different reading tasks call upon different skills and stances, they all also do require a common set of central skillsrecognizing letters, translating print information into phonological information, and accessing meaning of lexical items. Thus, depending on whether one focuses on the decoding that is prerequisite to using texts actively, or on the purposeful activity carried out with the text, one could well defend either position.

School-focused vs. home- and community-focused. For many children, school is the primary place where they have rich encounters with literacy. For other children, the literacy activities they engage in outside of school are more interesting, more challenging, and more motivating than those available in their school settings. The existence of rich opportunities for literacy engagement outside of school could be exploited to support school learning, but the children whose reading and writing occur mostly in school need particular attention and support.

\section{Conclusion}

I have used major disagreements as a frame for understanding research on early literacy development because questions of reading instruction and assessment have generated many controversies, and it is difficult to understand the discourse within the field of reading research without awareness of those disagreements. It is important to point out, though, that some of the virulent disagreements that have dominated the field of reading in previous periods have been resolved, by the introduction of evidence into the argument. Thus, for example, arguments about whether reading was a top-down or a bottom-up process were finally settled by findings about the eye movements of skilled readers (see Snow \& Juel, in press), which demonstrated that they fixated on most of the letters on the page. Similarly, many of the points of disagreement noted in this chapter may well be resolved by the progress of research on questions like what approaches to early intervention for reading difficulties are most effective, or the relative effectiveness of code-focused versus language-focused early literacy instruction for second language learners and children growing up in poverty. 


\section{References}

Barton, D. \& Hamilton, M. (1998). Local literacies: Reading and writing in one community. London/New York: Routledge.

Barton, D., Hamilton, M., \& Ivanic, R. (Eds.) (2000). Situated literacies: Reading and writing in context. London/New York : Routledge..

Bond, G.L., \& Dykstra, R. (1967). The cooperative research program in first-grade reading instruction. Reading Research Quarterly, 2, 5-42.

Bowey, J. (in press). Predictors of individual differences in learning to read. In M. Snowling \& C. Hulme (Eds.), The Science of Reading: A Handbook.

Bowey, J.A. (1995). On the contribution of phonological sensitivity to phonological recoding. Issues in Education: Contributions from Educational Psychology, 1, 6569.

Bush, G. W. (2001). Message to Congress (Budget outline). Washington, DC. Feb 27

Byrne, B., \& Fielding-Barnsley, R. (1989). Phonemic awareness and letter knowledge in the child's acquisition of the alphabetic principle. Journal of Educational Psychology, 81, 313-321.

Chall, J. S. (1996). Stages of reading development, $2^{\text {nd }}$ Edition. Fort Worth: Harcourt Brace College Publishers.

Davidson, R. \& Snow, C.E. (1996). Five-year-olds' interactions with fathers versus mothers. First Language, 16, 223-242.

Davidson, R.G., \& Snow, C.E. (1995). The linguistic environment of early readers. Journal of Research in Childhood Education, 10, 5-21.

Ehri, L. C., Nunes, S. R., Willows, D. M., Valeska Schuster, B., Yaghoub-Zadeh, Z., \& Shanahan, T. (2001). Phonemic awareness instruction helps children learn to read: Evidence from the National Reading Panel's meta-analysis. Reading Research Quarterly, 36(3), 250-287.

Eldering, L. \& Vedder, P. (1999). The Dutch experience with the Home Intervention Program for Preschool Youngsters (HIPPY). In L. Eldering \& P. M. Leseman (Eds.) Effective Early Education: Cross-cultural Perspectives, (pp. 235-258), NY: Falmer Press.

Garcia Marquez, G. (2003). Vivir para contarla. New York: Vintage Books.

Gee, J. P. (1996). Social linguistics and literacies: Ideology in discourses. London/ Bristol, PA: Taylor \& Francis.

Gee, J.P. (1999). Reading and the new literacy studies: Reframing the National Academy of Sciences report on reading. Journal of Literacy Research, 31, 355-374.

Gee, J.P. (2000). The limits of reframing: A response to Professor Snow. Journal of Literacy Research, 32, 121-128.

Goswami, U. (2001). Early phonological development and the acquisition of literacy. In S. B. Neuman \& D. K. Dickinson (Eds.), Handbook of Early Literacy Research (pp. 111-125). New York: The Guilford Press.

Hart, B. \& Risley, T. (1995). Meaningful differences in the everyday experience of young American children. Baltimore: P.H. Brookes. 
Hulme, C., Muter, V., Snowling, M., Stevenson, J. (2004). Phonemes, rimes, vocabulary, and grammatical skills as foundations of early reading development: Evidence from a longitudinal study. Developmental Psychology, 40, 665-681.

Jacobson, E. (2004). Community building in Japanese adult basic education. Unpublished doctoral thesis, Harvard Graduate School of Education.

Jordan, G., Porche, M. \& Snow, C. (2000). Project EASE: The effect of a family literacy project on kindergarten students' early literacy skills. Reading Research Quarterly, 45 (4), 524-546.

Kagitcibasi, C. (1999) Empowering parents and children: The case of the Turkish Early Enrichment Project. In L. Eldering \& P. M. Leseman (Eds.) Effective Early Education: Cross-cultural Perspectives, (pp. 235-258), NY: Falmer Press.

Lombard, A. D. (1994). Success begins at home: The past, present, and future of the Home Instruction Program for Preschool Youngsters. 2d ed. Guilford, Conn.: Dushkin Publishing Group.

Love, J., Kisker, E., Ross, C., Schoshet, P., Books-Gunn, J., Paulsell, D., Boller, K., Constantine, J., Vogel, C., Fuligni, A., Brady-Smith, C. (2002). Making a difference in the lives of infants, toddlers, and their families: The impacts of Early Head Start. Princeton, NJ: The Mathematica Policy Research, Inc. http://www.mathematica-mpr.com/publications/pdfs/ehsfinalsumm.pdf

Moats, L. (2004). Science, language, and imagination in the professional development of teachers. In McCardle P., Chhabra, V. (Eds.) The Voice of Evidence in Reading Research. Baltimore, MD: Paul H. Brookes Publishing Co.

Murnane, R., Levy, F. (2004) The new division of labor: How computers are creating the next job market. Princeton, NJ: Princeton University Press.

National Institute of Child Health and Human Development. (2000). Report of the National Reading Panel. Teaching children to read: An evidence-based assessment of the scientific research literature on reading and its implications for reading instruction (NIH Publication No. 00-4769). Washington, DC: U.S. Government Printing Office.

National Research Council. (1998). Preventing reading difficulties in young children. Washington, DC. National Academy Press.

Porche, M. V., \& Pallante, D. H. (2004). Sustained growth: A longitudinal analysis of a kindergarten intervention. In CS. Snow (Chair) Research Into Practice: A Literacy Research and Intervention Case Study. Paper presented at the American Educational Research Association Annual Meeting, San Diego, CA.

Purcell-Gates, G. (1991). Ability of well-read-to kindergartners to decontextualize/recontextualize experience into a written-narrative register. Language and Education: An International Journal, 5, 177-188.

Purcell-Gates, V. (1988). Lexical and syntactic knowledge of written narrative held by well-read-to kindergarteners and second graders. Research in the Teaching of English, 22, 128-160.

Reyna, V. (2004). Why scientific research: The importance of evidence in changing educational practice. In McCardle P., Chhabra, V. (Eds.) The Voice of Evidence in Reading Research. Baltimore, MD: Paul H. Brookes Publishing Co. 
Richmond, J. \& Ayoub, C. (1993). The evolution of early intervention philosophy. In Bryant, D. \& Graham, M. (Eds.) Implementing Early Intervention: From Research to Best Practice. New York: Guilford Press, pp.1-17.

Rolla San Francisco, A., Arias,M., \& Villars, R. (2004). Evaluating the impact of different early literacy interventions on low-income Costa Rican kindergartners' academic skills. Unpublished paper, Amigos del Aprendizaje, San Jose, Costa Rica.

Scarborough, H.S. (1998). Early identification of children at risk for reading disabilities: Phonological awareness and some other promising predictors. In Shapiro, K., Accardo, P.J. \& Capute, A.J. (Eds.), Specific Reading Disability: A View of the Spectrum (Pp. 77-121). Timonium, MD: York Press.

Sigel, I. (2004). Head Start—Revisiting a historical psychoeducational intervention: A revisionist perspective. In In Zigler, E., Styfco, S. (Eds.) The Head Start Debates pp. 45-60). Baltimore, MD: Paul H. Brookes Publishing Co.

Snow, C. E. \& Juel, C. (in press). Teaching children to read: What do we know about how to do it? In M. J. Snowling \& C. Hulme (Eds.) The Science of Reading: A Handbook. London: Blackwell.

Snow, C. E. \& Páez. M. (2004). The Head Start Classroom as an oral language environment: What should the performance standards be? In E. Zigler \& S. Styfco (eds.), The Head Start Debates (Friendly and Otherwise (pp. 215-244). Baltimore, MD: Brookes Publishing.

Snow, C. E., Tabors, P. O., Dickinson, D. K. Language development in the preschool years. In Dickinson, D. K., Tabors, P. O. (Eds.), (2001). Beginning Literacy with Language. (pp. 1 - 25). Baltimore: Paul H. Brookes Publishing Co.

Snow, C.E. (2000). On the limits of reframing: Rereading the National Academy of Sciences report on reading. Journal of Literacy Research, 32, 113-120.

Snow, C.E., Tabors, P.O., Nicholson, P., \& Kurland, B. (1995) SHELL: Oral language and early literacy skills in kindergarten and first grade children. Journal of Research in Childhood Education, 10, 37-48.

Stanovich, K. \& West, R. (1994). Reply to Taylor. Reading Research Quarterly, 29, 290-291.

Stanovich, K. E., West, R. F., \& Harrison, M. R. (1995). Knowledge growth and maintenance across the life span: The role of print exposure. Developmental Psychology, 31, 811-826.

Street, B.V. (1987) Literacy and social change: The significance of social context in the development of literacy programmes. In Wagner, D.A. (Ed.) The Future of Literacy in a Changing World. New York: Pergamon Press.

Street, B. V. (1995). Social literacies: critical approaches to literacy in development, ethnography, and education. London/New York: Longman.

Street, B. V. (2001). Literacy Empowerment in Developing Societies. In Verhoeven, L., \& Snow, C. (Eds.), (2001). Literacy and Motivation (pp. 291-300). Mahwah, New Jersey: Lawrence Erlbaum Associates.

Sulzby, E. (1985). Children's emergent reading of favorite storybooks: A developmental study. Reading Research Quarterly, 20, 458-481. 
Tabors, P. O., Roach, K. A., Snow, C.E. (2001) Home language and literacy environment final results. In Dickinson, D. K., Tabors, P. O. (Eds.), (2001). Beginning Literacy with Language. (pp.111 - 138). Baltimore: Paul H. Brookes Publishing Co.

Taylor, D. (1994). The trivial pursuit of reading psychology in the "real world": A response to West, Stanovich, and Mitchell. Reading Research Quarterly, 29, 276288.

Taylor, D. (1998). Beginning to read and the spin doctors of science: The political campaign to change America's mind about how children learn to read. Urbana, IL: National Council of Teachers of English.

Teale, W. \& Sulzby, E. (1986). Emergent Literacy: Writing and Reading. Norwood, NJ: Ablex Publishing Corporation.

Treiman, R., Tincoff, R., \& Richmond-Welty, D. (1996). Letter names help children to connect print and speech. Developmental Psychology, 32, 505-514. (H)

Walley, A. (1993) The role of vocabulary development in children's spoken word recognition and segmentation abilities. Developmental Review, 13, 286-350.

Watt, H. C. (2001). Writing in kindergarten teaches phonological awareness and spelling. Unpublished doctoral dissertation, Harvard Graduate School of Education.

West, R. F., Stanovich, K. E., \& Mitchell, H. R. (1993). Reading in the real world and its correlates. Reading Research Quarterly, 28, 34-50. (29, 290-291)

Westheimer, M. (Ed.) (2003). Parents making a difference: International research on the Home Instruction for Parents of Preschool Youngsters (HIPPY) Program. Jerusalem: The NCJW Research Institute for Innovation in Education, The Hebrew University.

Whitehurst, G., Massetti, G. (2004). How well does Head Start prepare children to learn to read? In Zigler, E., Styfco, S. (Eds.) The Head Start Debates (pp. 251-262). Baltimore, MD: Paul H. Brookes Publishing Co.

Whitehurst, G., Storch, S.A. (2001). The role of family and home in the literacy development of children from low-income backgrounds. Britto, P.R.,BrooksGunn, J. (Eds.) The Role of Family Literacy Environments in Promoting Young Children’s Emerging Literacy Skills. San Francisco, CA: Jossey-Bass. 